\title{
Solanum torvum inhibits Helicobacter pylori growth and mediates apoptosis in human gastric epithelial cells
}

\author{
YUAN-MAN HSU ${ }^{1}$, JING-RU WENG ${ }^{1}$, TSURNG-JUHN HUANG ${ }^{2}$, CHIH-HO LAI $^{3}$, \\ CHIU-HSIANG SU ${ }^{1}$ and CHANG-HUNG CHOU ${ }^{2}$ \\ ${ }^{1}$ Department of Biological Science and Technology; ${ }^{2}$ Research Center for Biodiversity and \\ Graduate Institute of Ecology and Evolutionary Biology; ${ }^{3}$ Department of Microbiology, \\ School of Medicine, China Medical University, Taichung, Taiwan, R.O.C.
}

Received October 8, 2009; Accepted December 28, 2009

DOI: $10.3892 /$ or_00000777

\begin{abstract}
Helicobacter pylori infection is associated with an increased risk for development of duodenal ulcers, gastric ulcers, gastric adenocarcinomas and gastric lymphomas. However, resistant strains have developed because of antibiotic treatment. In this study, the water, acetone, chloroform and methanol extracts of two Solancaceae plants, Solanum erianthum and Solanum torvum (ST), were tested for their anti-H. pylori activity. All of ST extracts were able to inhibit the growth of $H$. pylori and showed better activities against antibiotic strains than the reference strain. Among them, chloroform extract of ST (ST-C) possessed the strongest ability to inhibit $H$. pylori growth. Association assay was performed by the ST-C showing that ST-C was able to interrupt the association of bacteria to host cells. Furthermore, H. pylori-induced apoptosis could also be efficiently suppressed by the ST-C. It was able to interfere with the interaction between bacteria and host cells and also target $H$. pylori-induced gastric injury by suppressing apoptosis. Therefore, ST-C may offer a new approach for the treatment of $H$. pylori. Further studies on the elucidation of the molecular mechanisms of the growth inhibition on $H$. pylori by ST-C, and to identify active compounds in the plants are in progress.
\end{abstract}

\section{Introduction}

The Gram-negative bacterium Helicobacter pylori persistently colonizes the human stomach $(1,2)$. $H$. pylori-induced gastric inflammation might not cause symptoms in most infected persons, but is associated with an increased risk for

Correspondence to: Professor Chang-Hung Chou, China Medical University, 91 Hsueh-Shih Road, Taichung, Taiwan, R.O.C. E-mail: choumasa@mail.cmu.edu.tw

Key words: Helicobacter pylori, Solanum torvum, human gastric epithelial cells, apoptosis development of duodenal ulcers, gastric ulcers, gastric adenocarcinomas and gastric lymphomas. Therefore, $H$. pylori has been classified as a group 1 carcinogen $(3,4)$.

Many studies have showed that apoptosis plays an important role in the pathogenesis of various diseases (5). Homeostasis in the stomach is maintained through a balance between gastric epithelial proliferation and apoptosis (6). However, H. pylori infection affects the normal balance (6-11). In patients with gastric cancer, there is a disturbance in Bax (the pro-apoptotic protein) and Bcl-2 (the anti-apoptotic protein) balance induced by $H$. pylori (9). Several studies reported that the release of apoptosis-inducing factor from mitochondria is the major pathway involved in $H$. pyloriinduced apoptosis $(10,11)$.

In order to eliminate $H$. pylori infection, several treatments including at least one antibiotic in combination with a proton pump inhibitors have been applied (12). However, as other bacterial pathogens, antibiotic resistance to $H$. pylori is an increasing problem for eradicating infection (13). Therefore, finding a safe and efficient treatment to decrease the need or even replace antibiotics for eradicating $H$. pylori infection in human becomes necessary and an important task.

The Solancaceae family of plants is one of the three most important vegetable crops relevant to human nutrition and health (14). These crops produce biologically active secondary metabolites, such as alkaloids, flavonoids and terpenoids, which have beneficial effects in the diet. Alkaloids have anticancer activities (15-18). Flavonoids are anti-oxidation agents which can eliminate free radicals and suppress antibacterial ability (19-22). Terpenoids are extensively used for their aromatic qualities. They all play important roles in traditional herbal remedies and are under investigation for anti-bacterial, anti-neoplastic and other pharmaceutical effects (23-26).

In this study, two Solancaceae plants, Solanum erianthum and Solanum torvum (ST) which are all valued folk herbal medicine tested against the pathogen H. pylori. SE is used for treatment of metrorrhagia, edema, gout, carbuncles, eczema, toothache and dermatitis (27). The fruit juice of ST is used for the treatment of abscesses, jigger wounds, and skin infections. ST was used as a tonic and haemopoietic agents and for treatment of pain (28). This study was aimed at evaluating the anti-microbial activity and the effects of the 
SE extracts on the suppression of $H$. pylori-induced apoptosis on human gastric epithelial AGS cells.

\section{Materials and methods}

Preparation of plant extracts. The whole plants of SE and ST were collected at Nantou and Taichung Counties in the central Taiwan in October 2006 and voucher specimens were deposited in the Department of Biological Science and Technology, China Medical University. The whole dried plants $(2.0 \mathrm{~kg})$ of SE and ST were chipped into pieces and extracted with water, chloroform, acetone and methanol at room temperature. The various extracts of SE were concentrated under reduced pressure to afford the brown residue of water (15 g), chloroform (17 g), acetone (25 g) and methanol $(20 \mathrm{~g})$. The various extract of ST were concentrated under reduced pressure to afford the black residue of water (33 g), chloroform (22 g), acetone (30 g), and methanol $(39 \mathrm{~g})$. All of the extracts were dissolved in dimethyl sulfoxide (DMSO) and analyzed for their pharmacological activities.

Bacterial and cell culture. H. pylori strain 26695 (ATCC 700392), the reference strain, was obtained from the American Type Culture Collection (ATCC). The antibiotic resistance strains, V633, V1254, V1354 and V2356, were clinical isolates from a previous study $(29,30)$. These strains are all resistant to both metronidazole and clarithromycin, the antibiotics used to treat $H$. pylori infection. $H$. pylori was grown on blood agars under microaerophilic conditions at $37^{\circ} \mathrm{C}$ for 48-72 h. AGS cell line (ATCC CRL 1739; human gastric adenocarcinoma cell line) was purchased from the ATCC and was cultured in RPMI-1640 medium supplemented with $10 \%$ fetal bovine serum (FBS) and antibiotics $(100 \mathrm{U} / \mathrm{ml}$ of penicillin and $100 \mu \mathrm{g} / \mathrm{ml}$ of streptomycin).

Anti-microbial activity. Disc diffusion method was applied to determine the anti-microbial activity of plant extracts. A suspension of the $H$. pylori $\left(1 \times 10^{5}\right.$ cells $)$ was spread on Mueller-Hinton agar plates supplemented with $5 \%$ sheep blood. Filter paper discs (6 $\mathrm{mm}$ in diameter) were impregnated with $10 \mu \mathrm{l}$ of plant extracts and antibiotics and placed on the inoculated plates. These plates were incubated at $37^{\circ} \mathrm{C}$ for 48-72 $\mathrm{h}$. The diameters of the inhibition zones were measured in $\mathrm{mm}$. All the tests were replicated four times and the antibacterial activity was expressed as the mean of inhibition diameters $(\mathrm{mm})$ produced by the plant extracts.

Cell viability assay. AGS cells were seeded onto 24-well plates at a density of $5 \times 10^{4}$ cells/well for $24 \mathrm{~h}$. Indicated concentration of plant extracts were then added to the cells, while only adding $0.1 \%$ DMSO (solvent) in the control group and grown at $37^{\circ} \mathrm{C}$ for $24 \mathrm{~h}$. For determination of cell viability, the trypan blue exclusion protocol was used. Briefly, $\sim 10 \mu 1$ of cell suspensions in phosphate-buffered saline (PBS, pH 7.4) were mixed with $40 \mu 1$ of trypan blue and the numbers of stained (dead cells) and unstained cells (live cells) were counted using a hemocytometer. The cell viability was calculated as the percentage of cell survival after the treatment.
Association assay. AGS cells cocultured with PBS-resuspended $H$. pylori at the multiplicities of infection (MOI) of 100 were treated with plant extracts in the antibiotics-free RPMI-1640 supplemented with $10 \%$ FBS. Indicated concentration of plant extracts were then added to the cells, while only adding $0.1 \%$ DMSO (solvent) in the control group. Cell-associated bacteria were quantified $6 \mathrm{~h}$ after infection by osmotic lysis of host cells. Cell culture supernatants were removed gently, cells were washed with PBS and osmotic lysis was performed to calculate the total amount of bacteria. For this purpose, sterile water was added to infected cells after washing and cell lysates were resuspened with PBS and bacterial numbers were determined by plating serial dilutions on chocolate agar plates. The association activity was determined as the mean of triplicates. The bacteria associated with host cells included adherent and invaded ones. The results were expressed as the percentage of relative association of $H$. pylori as compared with the control group.

Preparation of cell extracts and Western blot analysis. AGS cells were seeded onto 6-well plates at a density of $5 \times 10^{5}$ cells/ well for $24 \mathrm{~h}$. The cells cocultured with PBS-resuspended $H$. pylori at MOI of 100 were treated with indicated amount of plant extracts or $0.1 \%$ DMSO (solvent) in the control group for $3 \mathrm{~h}$ in the antibiotics-free RPMI-1640 supplemented with $10 \%$ FBS. Infected cells were then lysed with ice-cold lysis buffer (0.5 M Tris- $\mathrm{HCl}, \mathrm{pH} 7.4,10 \%$ SDS, 0.5 M DTT). Protein concentration was determined by Bradford method (Bio-Rad, Hercules, CA, USA). Protein sample (20 mg) was loaded and separated on SDS-PAGE using the Hoefer mini VE system (Amersham Biosciences, Piscataway, NJ, USA). Proteins were transferred to a PVDF membrane (Hybond-P, Amersham) according to the manufacturer's instructions. Following the transfer, the membrane was washed with PBS and blocked for $1 \mathrm{~h}$ at $37^{\circ} \mathrm{C}$ with $5 \%$ fat-free milk in PBS and $0.1 \%$ of Tween-20 (PBST). The primary antibody ( $ß$-actin, caspase-8, Bid, Bad, Bax, cytochrome c, caspase- 9 and caspase-3; Santa Cruz Biotechnology, USA) was added at a dilution of $1 / 10000$. Blots were incubated with the peroxidaseconjugated secondary antibodies (horseradish peroxidaseconjugated goat anti-mouse IgG and goat anti-rabbit IgG; Santa Cruz Biotechnology) at a dilution of 1/1000. Following removal of the secondary antibody, blots were washed by PBST and developed by ECL-Western blotting system (Pierce, Rockford, IL, USA). Densities of the obtained immunoblots were quantified by Kodak digital science 1D (ver. 2.03) (Kodak, Rochester, NY, USA).

Statistical analysis. The differences between Solancaceae plant extract-treated and control groups in mean values were evaluated by Student's t-test using the SPSS software program (SPSS Inc., Chicago, IL, USA). Differences with a $\mathrm{P}<0.05$ were considered significant.

\section{Results}

SE and ST extracts inhibit H. pylori growth. The water (W), acetone (A), chloroform (C) and methanol (M) extracts of SE and ST at concentrations of $50-2.5 \mathrm{mg} / \mathrm{ml}$ were all tested for their anti-H. pylori activity based on the disc diffusion 
Table I. Effects of plant extracts against $H$. pylori reference strain.

\begin{tabular}{lccccc}
\hline & \multicolumn{5}{c}{$\begin{array}{c}\text { Inhibition zone (mm) } \\
\text { Concentration }(\mathrm{mg} / \mathrm{ml})\end{array}$} \\
\cline { 2 - 6 } Plant extract & 50 & 25 & 10 & 5 & 2.5 \\
\hline SE-W & - & - & - & - & - \\
SE-M & - & - & - & - & - \\
SE-A & - & - & - & - & - \\
SE-C & - & - & - & - & - \\
ST-W & 13 & - & - & - & - \\
ST-M & 10 & 9.5 & - & - & - \\
ST-A & 9 & 9 & - & - & - \\
ST-C & 17 & 16.5 & 12.5 & 9 & - \\
\hline
\end{tabular}

-, No inhibition observed.

Table II. Effects of SE and ST extracts against antibioticresistant $H$. pylori strains.

\begin{tabular}{lccccc}
\hline & \multicolumn{5}{c}{$\begin{array}{c}\text { Inhibition zone (mm) } \\
\text { H.pylori strain }\end{array}$} \\
\cline { 2 - 6 } Plant extract $^{\mathrm{a}}$ & 26695 & V633 & V1254 & V1354 & V2356 \\
\hline SE-W & - & - & - & - & - \\
SE-M & - & 10.5 & 13 & 11.25 & 10.75 \\
SE-A & - & 11.5 & 12.75 & 10.75 & 10.5 \\
SE-C & - & 13 & 11.5 & 10.75 & 10.5 \\
ST-W & 13 & 12 & 13.75 & 16.75 & 20.5 \\
ST-M & 10 & 10.5 & 11 & 9.5 & 10 \\
ST-A & 9 & 9.5 & 11 & 10 & 11 \\
ST-C & 17 & 12 & 14 & 13 & 12.5 \\
CLR $^{\mathrm{b}}$ & 44.25 & - & - & - & - \\
MTZ $^{c}$ & 31 & - & - & - & - \\
\hline
\end{tabular}

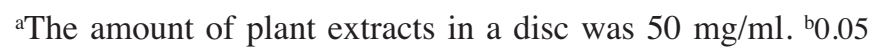
$\mathrm{mg} / \mathrm{ml}$ of clarithromycin. ${ }^{\mathrm{c}} 0.8 \mathrm{mg} / \mathrm{ml}$ of metronidazole.

method. DMSO $(0.1 \% \mathrm{v} / \mathrm{v})$ was used as negative control and showed no effect. As shown in Table I, the ST extracts were more active than SE extracts. The chloroform extract of ST (ST-C) exhibited the strongest anti-microbial activity against the reference strain. It was able to inhibit $H$. pylori at the concentration of $5 \mathrm{mg} / \mathrm{ml}$ with $9 \mathrm{~mm}$ of inhibition zone. The SE extracts were not effective against the reference strain, even up to the concentration of $50 \mathrm{mg} / \mathrm{ml}$ of the plant extracts.

Based on the inhibitory activity against $H$. pylori reference strain, we tested the activity of SE and ST extracts also against four clinical strains (Table II). Those analyzed strains were isolated from $H$. pylori-positive patients who failed in a triple treatment (lansoprazole, clarithromycin and

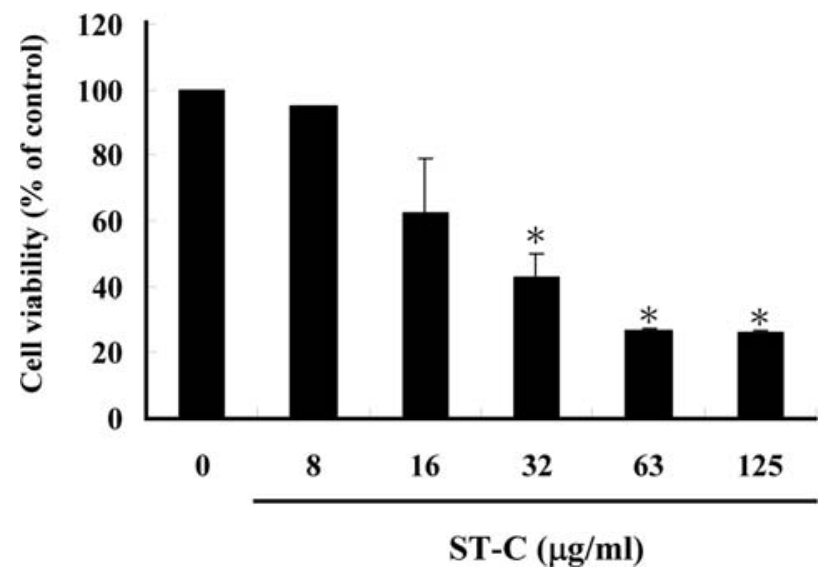

Figure 1. Effects of ST-C on the viability of AGS cells. The results are representative of three independent experiments carried out in triplicate. The error bars indicate standard deviations. ${ }^{*} \mathrm{P}<0.05$.

metronidazole) (29) and those strains were also tested for multiple drug-resistant (30). As we expected, all the clinical isolates were resistant to clarithromycin (CLR) at $0.05 \mathrm{mg} / \mathrm{ml}$ and metronidazole (MTZ) at $0.8 \mathrm{ml} / \mathrm{ml}$, while reference strain was sensitive to both antibiotics with inhibition zone of $44.25 \mathrm{~mm}$ (CLR) and $31 \mathrm{~mm}$ (MTZ). All of the ST extracts were able to inhibit the growth of all $H$.pylori strains at $50 \mathrm{mg} / \mathrm{ml}$. ST-W could even inhibit strain V2356 with a $20.5 \mathrm{~mm}$-zone. ST-C also showed better activities against clinical strains than reference strains. Interestingly, the organic solvent extracts of SE (SE-M, SE-A and SE-C) did not possess inhibitory activity against reference strain at concentration of $50 \mathrm{mg} / \mathrm{ml}$, however, they showed stronger activity against multidrug-resistant strains with inhibition zone of 10.5-13 mm. Among all the plant extracts, ST-C was the best for eradicating $H$. pylori infection.

Viability of AGS cells after treated with ST-C. Based on the anti-microbial activity, ST-C was found to have strong activity against $H$. pylori. In order to determine the treating dosage of ST-C, the viability of AGS cells was performed. ST-C at $32 \mu \mathrm{g} / \mathrm{ml}$ significantly decreased $57 \%$ of the viable cells (Fig. 1). At the concentration of $8 \mu \mathrm{g} / \mathrm{ml}, 95 \%$ of AGS cells were not affected after $24 \mathrm{~h}$ treatment. To investigate the effect of ST-C on interaction between AGS cells and $H$. pylori, the low-toxic dosage of ST-C $(<32 \mu \mathrm{g} / \mathrm{ml})$ was chosen for further assays.

ST-C inhibited the association of H. pylori to AGS cells. We further analyzed the effect of ST-C on association of $H$. pylori to AGS cells (Fig. 2). ST-C treatment significantly decreased the association of $H$. pylori to AGS cells. At the concentration of $5 \mu \mathrm{g} / \mathrm{ml}$, it showed a $57 \%$ decrease. However, there was no significant difference in inhibiting bacteria association within the dose range of $5-20 \mu \mathrm{g} / \mathrm{ml}$ and the cell viability was not affected at this range.

ST-C suppressed H. pylori-mediated apoptosis in AGS cells. We further examined that the effect of ST-C on H. pylorimediated apoptosis in AGS cells. The expression of caspase-8, 


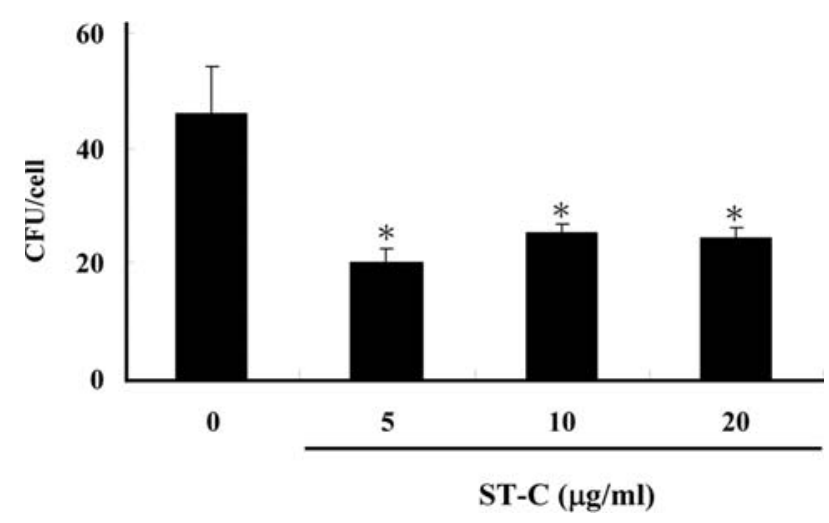

Figure 2. The effect of ST-C on H. pylori association in AGS cells. The results are representative of three independent experiments carried out in triplicate. The error bars indicate standard deviations. ${ }^{*} \mathrm{P}<0.05$.

Bid, Bad, Bax, cytochrome c, caspase- 9 and caspase- 3 in infected cells were monitored (Fig. 3). Compared with untreated cells, ST-C significantly suppressed the expression of caspase-8, Bid, Bad, cytochrome c, caspase-9 and caspase-3 in a dose-dependent manner. However, the expression of the anti-apoptotic protein Bax was up-regulated. These data indicated that ST-C treatment could block H. pylori-mediated apoptosis in AGS cells.

\section{Discussion}

S. torvum (ST) is one of the most valued folk herbal medicines for treatment of abscesses, jigger wounds, skin infections and has been used as a tonic and haemopoietic agents and for treatment of pain (28). This is the first study to show that the chloroform extract of ST (ST-C) strongly inhibits $H$. pylori growth and also interrupts the association of bacteria to host cells. H. pylori-induced apoptosis was also efficiently suppressed by the extract.

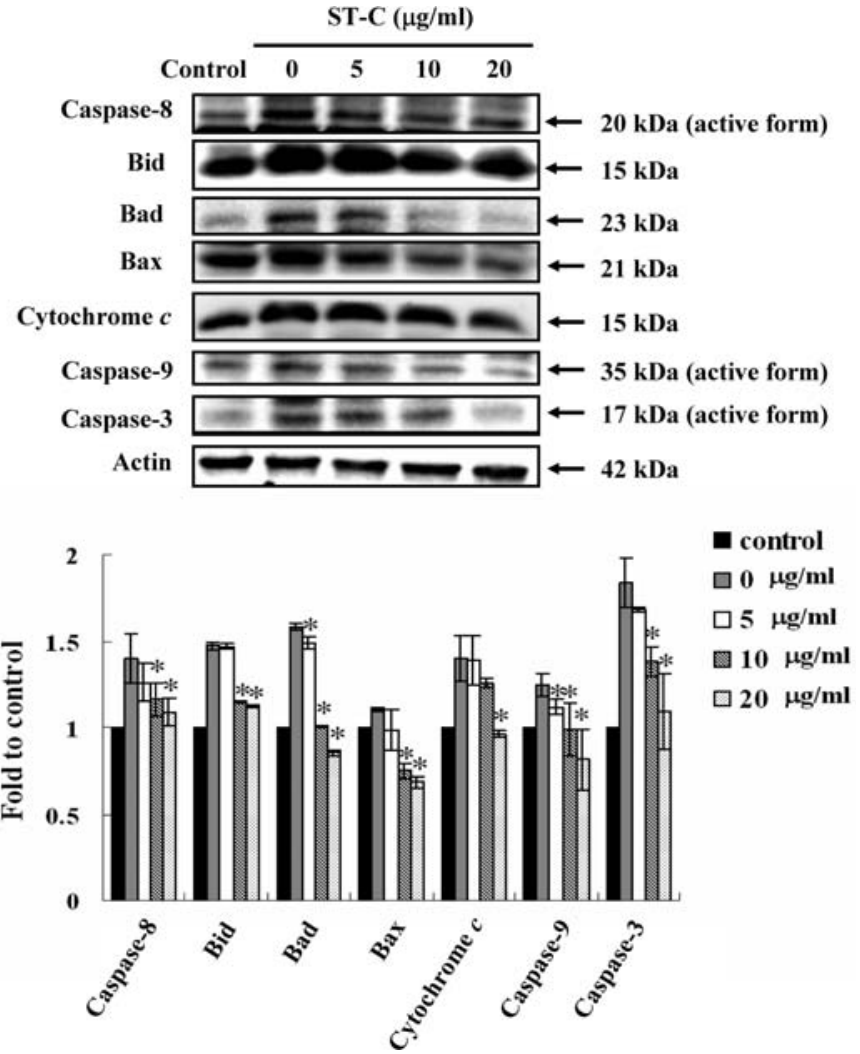

Figure 3. Effect of ST-C on the expression levels of caspase-8, Bid, Bad, Bax, cytochrome c, caspase- 9 and caspase- 3 on $H$. pylori-infected AGS cells. ${ }^{*} \mathrm{P}<0.05$ compared with control groups (uninfected cells). All of the assays were replicated in three independent experiments.

Several treatments are used as a means to eradicate $H$. pylori infection, all include at least one antibiotic in combination with a proton pump inhibitor $(2,12)$. The effectiveness of the treatment has been impaired by increasing drug resistance strains $(13,31)$. In this study, ST-C showed a strong ability in inhibiting the growth of $H$. pylori, including

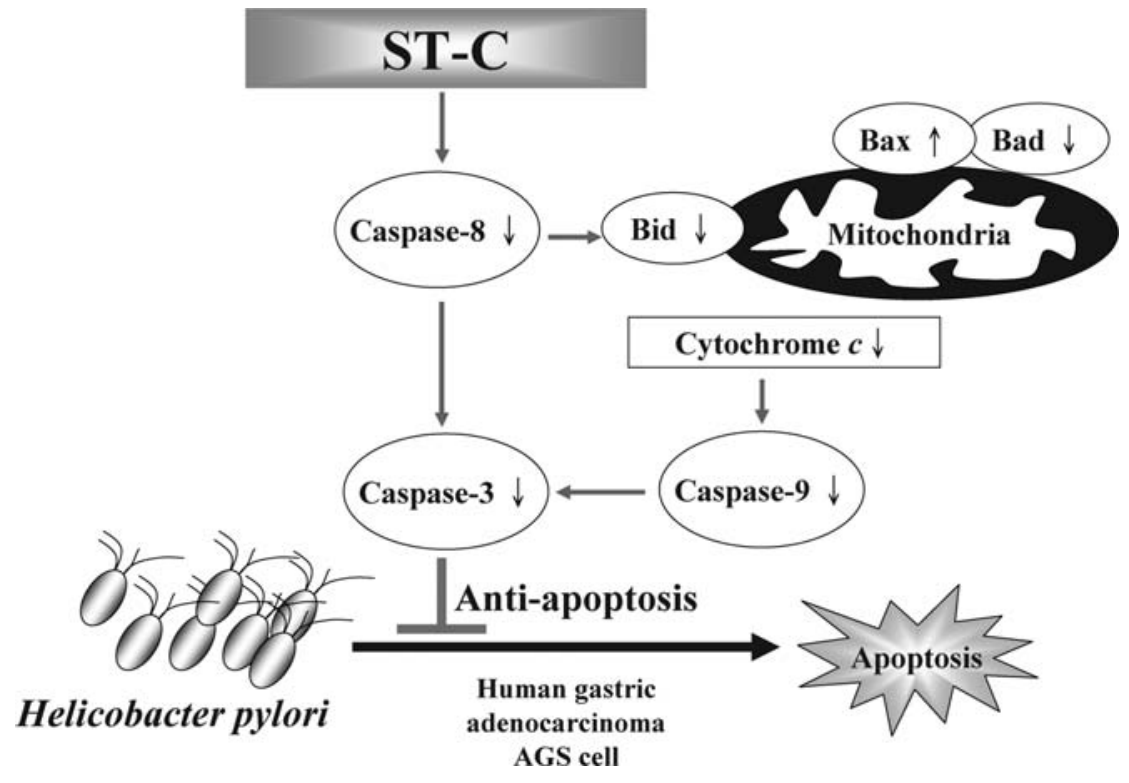

Figure 4. Hypothetical inhibitory mechanisms of ST-C in H. pylori-mediated apoptosis in AGS cells. 
multidrug-resistant strains which were isolated from $H$. pyloripositive patients who failed in a triple treatment.

The association of $H$. pylori to AGS cells was also interrupted by ST-C. Several studies have showed that apoptosis plays an important role in the pathogenesis of various diseases (5). It has been showed that $H$. pylori induced apoptosis in epithelial cells mainly through the death receptor leading to the cleavage of pro-caspase- 8 and Bid, release of chytochrome $\mathrm{c}$ from mitochondria and activation of subsequent downstream apoptotic pathway $(10,11)$. ST-C was able to interfere with the interaction between bacteria and host cells and also target $H$. pylori induced gastric injury by suppressing apoptosis (Fig. 4), therefore, ST-C may offer a new approach for the treatment of $H$. pylori. Further studies on the elucidation the molecular mechanisms of the growth inhibition on $H$. pylori by ST-C and to identify active compounds in the plants are in progress.

\section{Acknowledgements}

This investigation was supported by research grants from the Committee on Chinese Medicine and Pharmacy, Department of Health, Executive Yuan, Taiwan (CCMP96-RD-210 and CCMP97-RD-210) and China Medical University (CMU95339, CMU96-089, CMU96-065, CMU97-082 and CMU97275).

\section{References}

1. Kusters JG, van Vliet AH and Kuipers EJ: Pathogenesis of Helicobacter pylori infection. Clin Microbiol Rev 19: 449-490, 2006.

2. Amieva MR and El-Omar EM: Host-bacterial interactions in Helicobacter pylori infection. Gastroenterology 134: 306-323, 2008.

3. Peek RM Jr and Blaser MJ: Helicobacter pylori and gastrointestinal tract adenocarcinomas. Nat Rev Cancer 2: 28-37, 2002.

4. Correa P: The biological model of gastric carcinogenesis: IARC Sci Publ 157: 301-310, 2004.

5. Gao LY and Kwaik YA: The modulation of host cell apoptosis by intracellular bacterial pathogens. Trends Microbiol 8: 306-313, 2000

6. Xia HH and Talley NJ: Apoptosis in gastric epithelium induced by Helicobacter pylori infection: implications in gastric carcinogenesis. Am J Gastroenterol 96: 16-26, 2001.

7. Piotrowski J, Skrodzka D, Slomiany A and Slomiany BL: Helicobacter pylori lipopolysaccharide induces gastric epithelial cells apoptosis. Biochem Mol Biol Int 40: 597-602, 1996.

8. Moss SF, Calam J, Agarwal B, Wang S and Holt PR: Induction of gastric epithelial apoptosis by Helicobacter pylori. Gut 38: 498-501, 1996

9. Bartchewsky W Jr, Martini MR, Squassoni AC, et al: Effects of Helicobacter pylori infection on the expressions of Bax and Bcl-2 in patients with chronic gastritis and gastric cancer. Dig Dis Sci (In press).
10. Maeda S, Yoshida H, Mitsuno Y, et al: Analysis of apoptotic and antiapoptotic signalling pathways induced by Helicobacter pylori. Mol Pathol 55: 286-293, 2002.

11. Ashktorab H, Dashwood RH, Dashwood MM, et al: H. pyloriinduced apoptosis in human gastric cancer cells mediated via the release of apoptosis-inducing factor from mitochondria. Helicobacter 13: 506-517, 2008.

12. Ables AZ, Simon I and Melton ER: Update on Helicobacter pylori treatment. Am Fam Physician 75: 351-358, 2007.

13. Egan BJ, Marzio L, O'Connor H and O'Morain C: Treatment of Helicobacter pylori infection. Helicobacter 13 (Suppl 1): 35-40, 2008.

14. Lee MR: The Solanaceae: foods and poisons. J R Coll Physicians Edinb 36: 162-169, 2006.

15. Kupchan SM, Barboutis SJ, Knox JR and Cam CA: Betasolamarine: tumor inhibitor isolated from Solanum dulcamara. Science 150: 1827-1828, 1965.

16. Cham BE, Gilliver M and Wilson L: Antitumour effects of glycoalkaloids isolated from Solanum sodomaeum. Planta Med 53: 34-36, 1987.

17. Hu K, Kobayashi H, Dong A, Jing Y, Iwasaki S and Yao X: Antineoplastic agents. III: steroidal glycosides from Solanum nigrum. Planta Med 65: 35-38, 1999.

18. Kuo KW, Hsu SH, Li YP, et al: Anticancer activity evaluation of the solanum glycoalkaloid solamargine. Triggering apoptosis in human hepatoma cells. Biochem Pharmacol 60: 1865-1873, 2000.

19. McKay DL and Blumberg JB: A review of the bioactivity and potential health benefits of peppermint tea (Mentha piperita L.). Phytother Res 20: 619-633, 2006.

20. McKay DL and Blumberg JB: A review of the bioactivity and potential health benefits of chamomile tea (Matricaria recutita L.). Phytother Res 20: 519-530, 2006.

21. Sengupta A, Ghosh S and Bhattacharjee S: Allium vegetables in cancer prevention: an overview. Asian Pac J Cancer Prev 5: 237-245, 2004

22. Odontuya G, Hoult JR and Houghton PJ: Structure-activity relationship for antiinflammatory effect of luteolin and its derived glycosides. Phytother Res 19: 782-786, 2005.

23. Gang DR: Evolution of flavors and scents. Annu Rev Plant Biol 56: 301-325, 2005.

24. Stone MJ and Williams DH: On the evolution of functional secondary metabolites (natural products). Mol Microbiol 6: 29-34, 1992.

25. Williams DH, Stone MJ, Hauck PR and Rahman SK: Why are secondary metabolites (natural products) biosynthesized? J Nat Prod 52: 1189-1208, 1989

26. De Marino S, Borbone N, Gala F, et al: New constituents of sweet Capsicum annuum $L$. fruits and evaluation of their biological activity. J Agric Food Chem 54: 7508-7516, 2006.

27. Zhou LX and Ding Y: A cinnamide derivative from Solanum verbascifolium L. J Asian Nat Prod Res 4: 185-187, 2002.

28. Chah KF, Muko KN and Oboegbulem SI: Antimicrobial activity of methanolic extract of Solanum torvum fruit. Fitoterapia 71: $187-189,2000$

29. Poon SK, Chang CS, Su J, et al: Primary resistance to antibiotics and its clinical impact on the efficacy of Helicobacter pylori lansoprazole-based triple therapies. Aliment Pharmacol Ther 16: 291-296, 2002

30. Lai CH, Kuo CH, Chen PY, Poon SK, Chang CS and Wang WC: Association of antibiotic resistance and higher internalization activity in resistant Helicobacter pylori isolates. J Antimicrob Chemother 57: 466-471, 2006

31. Cavallaro LG, Egan B, O'Morain C and Di Mario F: Treatment of Helicobacter pylori infection. Helicobacter 11 (Suppl 1): 36-39, 2006. 